\title{
Prevalence of dyslipidemia and its association with disease activity in patients with rheumatoid arthritis attending Rizgary Teaching Hospital in Erbil City

Abstract
Background and objective: This study aimed to measure the prevalence of dyslipidemia

Background and objective: This study aimed to measure the prevalence of dyslipidemia in patients with rheumatoid arthritis compared with healthy control people and find out the correlation between dyslipidemia and disease activity.

Methods: A prospective case-control was done. A total of 100 female patients with rheumatoid arthritis were included in the study. This study was conducted at the Rheumatology Out-patient Clinic in Rizgary Teaching Hospital, Erbil City over seven months from April 2013 to October 2013. Patients who fulfilling the 1987 revised American College of Rheumatology and 2010 American College of Rheumatology/European League against rheumatism classification criteria for rheumatoid arthritis and 100 healthy female age-matched controls with the mean age for both groups being 45. Fasting lipid profiles of cases and controls were estimated after an overnight fasting of 12 hours. Association between lipid profile and disease activity using disease activity score DAS 28 , inflammatory markers (CRP and ESR) was also determined.

Results: Rheumatoid arthritis patients showed a higher prevalence of associated dyslipidemia $(47 \%)$ in comparison to control $(5 \%), P=0.004$. There was a significant reduction in serum high density lipoproteins $(P=0.04)$, with significant elevation of serum total cholesterol, triglyceride, low density lipoprotein and very low density lipoprotein ( $P=0.001,0.004,0.04$ and 0.05 , respectively) in comparison to controls. There was a significant relation between disease activity score 28 and serum high density lipoproteins $(P<0.001)$ and there was a significant relation between ESR and triglyceride $(P=0.05)$.

Conclusion: is frequent among the patients with rheumatoid arthritis and highly associated with active rheumatoid arthritis. Serum high density lipoproteins significantly reduced while other parameters of lipid profiles significantly increased in comparisons to control.

Keywords: Rheumatoid arthritis; Dyslipidemia; Disease activity.

\section{Introduction}

Rheumatoid arthritis (RA) is a chronic systemic autoimmune inflammatory disease that affects all ethnic groups throughout the world ${ }^{1}$ characterized by symmetric erosive synovitis. ${ }^{2}$ Females are 2.5 times more likely to be affected than males. ${ }^{3}$ The onset of disease can occur at any age, but peak incidence occurs within the fourth and fifth decade of life. ${ }^{4,5}$ The overall prevalence of rheumatoid arthritis is $1 \%$ to $2 \%$, and it steadily increases to $5 \%$ in women by the age of $70 .^{6-8}$ Rheumatoid arthritis is the most common form of inflammatory arthritis that affects diarthrodial joint. $^{9}$ Most commonly, the onset of symptoms of joint pain and swelling is insidious, occurring over weeks to months. ${ }^{10}$ Patients with RA have an increased mortality when compared with age-matched controls, primarily due to cardiovascular disease. This is most marked in those with severe disease, with a reduction in expected life span by 8-15 years. ${ }^{11}$ Dyslipidemia is increasingly recognized as an important contributory factor in the development of cardiovascular disease. $^{12}$ An epidemiological study has

* Erbil Directorate of Health, Erbil, I raq.

** Department of internal Medicine, College of Medicine, Hawler Medical University, Erbil, I raq. 
proposed that there is increase mortality in RA which is partly due to atherosclerosis. ${ }^{13,14}$ RA patients have been found to have altered concentrations of lipids and lipoprotein fractions in serum and synovial fluid. ${ }^{15,16}$ This study aimed to measure the prevalence of dyslipidemia in patients with RA compared with healthy control people and find out the correlation between dyslipidemia and disease activity.

\section{Methods}

A prospective case control was done. This study was conducted at the outpatient clinic of the Rheumatology Unit, Rizgary Teaching Hospital, Erbil city. The study was carried out over seven months from April 2013 to October 2013. This study included 100 female patients with RA fulfilling the 1987 revised American College of Rheumatology $(A C R)^{17}$ and 2010 American College of Rheumatology/ European League against Rheumatism classification criteria for $\mathrm{RA}^{18}$ and 100 healthy female age-matched controls. The age of all the patients and controls was between 20-70 years old. A non-random (convenient) sampling technique was used to recruit the cases and controls. History of smoking or patients suffering from a condition that affects the lipid profile such as diabetes mellitus, ischemic heart disease, renal impairment, liver and thyroid functional abnormalities, Cushing syndrome and obesity (BMI >30) were excluded. Also, any patients received medications affecting lipid metabolism such as beta blocker, diuretics, cyclosporine, oral contraceptive pills (OCP), patients who received oral or intra-articular steroid till one month before the study and pregnant women were excluded. A detailed history from each patient was taken, and full clinical examination including articular, extra -articular and monitoring disease activity using (DAS 28) was performed. $10 \mathrm{ml}$ of blood were obtained from the vein by VACUTAINER and collected in VACUTEST both gelatin (REF 10176) and EDTA tube (REF 13510) within 3 hours, the blood was centrifuged at $1000 \mathrm{rpm}$ (round per minute) for about 3 minutes using KUBOTA 5200 device. The blood in EDTA tube was used for measuring ESR while the blood in gelatin tubes were used for biochemical analysis including blood sugar, thyroid function test, renal function test and liver function test. The analysis was done in Rizgary Hospital's laboratory at the same times. After 12 hour fasting, blood samples of the subjects were obtained from antecubital vein between 8 and 11a.m. The samples were centrifuged within 3 hours in Rizgary Hospital's laboratory at $3000 \mathrm{rpm}$ for 3 minutes. The serum was then collected and stored at -30 degrees over six months. Then the lipid profile including the levels of total serum cholesterol (TC), low density lipoprotein cholesterol (LDL), high density lipoprotein cholesterol (HDL), very low density lipoprotein (VLDL) and triglyceride (TG) were measured for all subjects in private. Serums TC, HDL, TG were assayed by enzymatic methods (colorimetry) using kit CHOD (REF 1500010). LDL and VLDL values were calculated using the standard formula TC-HDL-TG/5, TG/5 respectively. Normal range of serum TG $<150 \mathrm{mg} / \mathrm{dl}$, serum cholesterol $<200 \mathrm{mg} / \mathrm{dl}$, serum HDL $>40$ $\mathrm{mg} / \mathrm{dl}$, serum LDL $<130 \mathrm{mg} / \mathrm{dl}$, serum VLDL up to $30 \mathrm{mg} / \mathrm{dl}$. It is known that women have higher levels of high density lipoprotein (HDL) than men, the sex difference in HDL cholesterol level usually assumed to be due to biologic factors and may be related to environmental factors. Also, Accp, RFT, TFT, FBS, LFT, ECG, CRP and ESR were performed. Dyslipidemia, defined as elevated total cholesterol or low density lipoproteins or low levels of high density lipoproteins, is an important risk factor for coronary heart disease and stroke.

\section{Statistical analyses:}

Data was entered into the Microsoft Excels and then analyzed by using the statistical package for the social sciences (version 16). Statistical analysis included 
both descriptive and inferential statistics for analyzing the data obtained from the study to explain the results. Student's t test was used for comparing the variables of the groups including percentage, mean and standard deviation. Spearman's' rho correlation coefficient used for association between lipid profiles with inflammatory markers (ESR, CRP) and disease activity score 28. We also used Chi square for comparisons between the cases and controls' lipid profiles. The statistical significance was set at the level of $\leq 0.05$.

\section{Results}

Figure 1 showed that $34 \%$ of patients were in the fifth decade of life and $22 \%$ were in the fourth decade of life. $67 \%$ of rheumatoid arthritis patients were RF positive while $33 \%$ of them were negative as shown in Figure 2. Anti-CCP was positive in 52 , and $48 \%$ was negative in rheumatoid arthritis patients as shown in Figure 3.

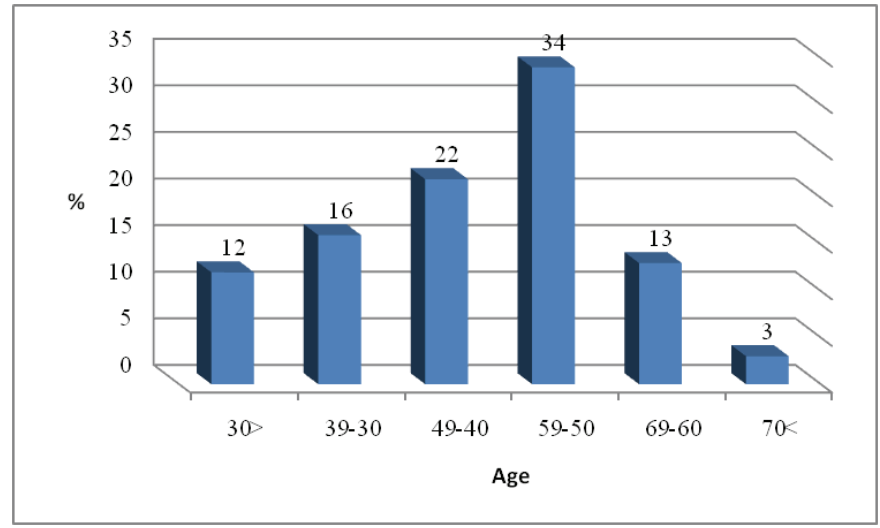

Figure 1: Distribution of studied patients according to the age.

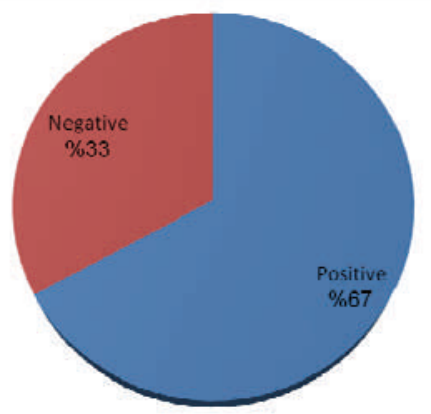

Figure 2: Rheumatoid factor distribution in rheumatoid arthritis patients.

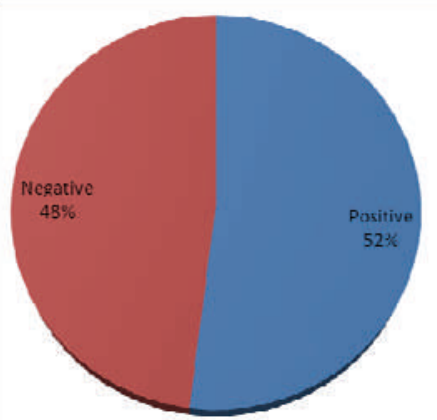

Figure 3: Anti cyclic citrullinated peptide antibody distribution in rheumatoid arthritis patients 
$47 \%$ of patients with RA had various type of dyslipidemia statistically significant in comparison to control group $5 \%$ as shown in Table 1. There was a significant reduction in serum HDL of RA patients in comparison to controls $(P=0.04)$. The mean \pm SD of HDL was $44.6 \pm 10.9$ in cases and $52.3 \pm 17.2$ in controls. There was a highly significant elevation in serum TG of RA patients (cases) in comparison to controls $(P=0.004)$. The mean \pm SD of serum TG was $148.8 \pm 70.9$ in RA patients and $116.4 \pm 48.6$ in control group. There was a highly significant increase in serum total cholesterol in RA patients in comparison to controls $(P<0.001)$.
The mean \pm SD of serum TC was $177.6 \pm 39.2$ in cases and $162.7 \pm 33.6$ in controls. There was a highly significant increase in serum low density lipoprotein in RA patients in comparison to controls $(P=0.04)$. The mean \pm SD of serum LDL was $101.7 \pm 30.9$ in cases and $86.6 \pm 30.1$ in controls. There was a statistically significant elevation in serum VLDL in RA patients in comparison with age matched control $(P=0.05)$. The Mean \pm SD of serum VLDL was $29.8 \pm 14.8$ in RA patients and $25.5 \pm 12.8$ in control group. Details of comparison between cases and controls according to serum lipid profile are shown in Table 2.

Table 1: Distribution of dyslipidemia in RA patients in comparisons to control groups.

\begin{tabular}{lccc}
\hline & \multicolumn{2}{c}{ Dyslipidemia } & P value \\
\hline & Yes & NO & \\
Case & $(47) 47 \%$ & $(53) 53 \%$ & 0.004 \\
Control & $(5) 5 \%$ & $(95) 95 \%$ & \\
\hline
\end{tabular}

Table 2: Comparison between case and control according to serum lipid profile.

\begin{tabular}{|c|c|c|c|c|c|c|c|}
\hline \multirow[t]{2}{*}{ Lipid profiles } & \multicolumn{2}{|c|}{ case } & \multicolumn{2}{|c|}{ Control } & \multicolumn{2}{|c|}{ total } & \multirow[t]{2}{*}{$P$ value } \\
\hline & Normal & Abnormal & Normal & Abnormal & $\begin{array}{l}\text { Case } \\
\text { \&control } \\
\text { (normal) }\end{array}$ & $\begin{array}{c}\text { Case } \\
\text { \&control } \\
\text { (abnormal) }\end{array}$ & \\
\hline Serum HDL & $\begin{array}{c}62 \\
(45.3 \%)\end{array}$ & $\begin{array}{c}38 \\
(60.3 \%)\end{array}$ & $\begin{array}{c}75 \\
(54.7 \%)\end{array}$ & $\begin{array}{c}25 \\
(39.7)\end{array}$ & 137 & 63 & 0.04 \\
\hline Serum TG & $\begin{array}{c}41 \\
(65.1 \%)\end{array}$ & $\begin{array}{c}59 \\
(0.72 \%)\end{array}$ & $\begin{array}{c}22 \\
(34.92 \\
\%\end{array}$ & $\begin{array}{c}78 \\
(56.93 \%)\end{array}$ & 63 & 137 & 0.004 \\
\hline $\begin{array}{l}\text { Serum } \\
\text { cholesterol }\end{array}$ & $\begin{array}{c}27 \\
(75 \%)\end{array}$ & $\begin{array}{c}73 \\
(44.5 \%)\end{array}$ & $\begin{array}{c}9 \\
(25 \%)\end{array}$ & $\begin{array}{c}91 \\
(55.5 \%)\end{array}$ & 36 & 164 & $<0.001$ \\
\hline Serum LDL & $\begin{array}{c}20 \\
(66.7 \%)\end{array}$ & $\begin{array}{c}80 \\
(47.1 \%)\end{array}$ & $\begin{array}{c}10 \\
(33.3 \%)\end{array}$ & $\begin{array}{c}90 \\
(52.9 \%)\end{array}$ & 30 & 170 & 0.04 \\
\hline Serum VLDL & $\begin{array}{c}38 \\
(58.5 \%)\end{array}$ & $\begin{array}{c}62 \\
(45.9 \%)\end{array}$ & $\begin{array}{c}27 \\
(41.5 \%)\end{array}$ & $\begin{array}{c}73 \\
(54.1 \%)\end{array}$ & 65 & 135 & 0.05 \\
\hline
\end{tabular}


There was no statistically significant association between ESR and lipid profiles except for serum triglyceride, which was significantly related with ESR $(P=0.05)$ as shown in Table 3. Out of 11 RA patients on remission, five patients had dyslipidemia. Out of 12 RA patients of low active disease, four patients had dyslipidemia. Out of 48 RA patients of moderate disease active, 20 patients had dyslipidemia. Among 29 RA patients with highly disease activity, 18 patients had dyslipidemia. These differences were statistically not significant $(P=0.6)$ as shown in Table 4.

Table 3: Correlation between ESR and lipid profiles in RA patients.

$\begin{array}{lcc}\text { Lipid profile } & \begin{array}{c}\text { Spearman's' coefficient } \\ \text { correlation(ESR) }\end{array} & P \text { value }\end{array}$

\begin{tabular}{lcc}
\hline Serum TC & 0.021 & 0.07 \\
Serum TG & 0.088 & 0.05 \\
Serum HDL & 0.013 & 0.08 \\
Serum LDL & 0.007 & 0.06 \\
Serum VLDL & 0.07 & 0.07 \\
\hline
\end{tabular}

Table 4: Correlation between disease activity score and dyslipidemia.

\begin{tabular}{lcccc}
\hline $\begin{array}{l}\text { Status of disease } \\
\text { activity score }\end{array}$ & $\begin{array}{c}\text { Number of } \\
\text { patients }\end{array}$ & \multicolumn{2}{c}{ Dyslipidemia } & P value \\
\hline Remission & 11 & 5 & 6 & \\
& & $10.6 \%$ & $11.32 \%$ & \\
Low & 12 & 4 & 8 & \\
& & $8.5 \%$ & $15.09 \%$ & 0.698 \\
Moderate & 48 & 20 & 28 & \\
& & $42.55 \%$ & $52.8 \%$ & \\
High & 29 & 18 & 11 & \\
Total & 100 & $62.06 \%$ & $37.93 \%$ & \\
\hline
\end{tabular}




\section{Discussion}

Patients with RA are at increased risk for cardiovascular disease, which accounts for about half of all deaths in these patients. ${ }^{19}$ This is attributed to accelerated atherosclerosis as a result of both systemic inflammatory burden and high prevalence of traditional risk factors for cardiovascular disease. ${ }^{20,21}$ In this study RA occurred in all age groups between 20-70 years, which showed that $34 \%$ of them were between 50 to 59 years and $22 \%$ were between 40 to 49 years of age; this is in accordance with another study which mentioned that RA usually affects people above 40 years old ${ }^{22}$ and also matched with the study done in Baghdad, Iraq 2013. ${ }^{23}$ This is due to many reasons that depress immunity as stress and long duration of exposure to environmental antigens that cause stimulation of auto-reactive immune cell. ${ }^{24}$ In comparison to the control group, RA patients showed a statistically significant higher prevalence of associated dyslipidemia ( $5 \%$ of control versus $47 \%$ of cases). This was near to the study done in Pakistan $2012^{25}$ which the prevalence was $45 \%$ but disagreed with the study done in Tunisia $2011^{26}$ in which the prevalence was $65.9 \%$. This may be due to the type of study which took only patients with active rheumatoid arthritis or drugs in which most of their patients were on combinations of drugs disease modifying antirheumatic drug (DMARD) and Tumor necrosis factor inhibitor that they have effects on lipid profile. $^{27}$ In this study we found that patients diagnosed with RA had significantly reduced levels of HDLcholesterol in comparison to control groups. This matched with many other studies done in all of Pakistan 2012, ${ }^{25}$ Tunisia 2011, ${ }^{26}$ Malaysia 2012, ${ }^{28}$ South India, ${ }^{29}$ Saudi Arabia 2013, ${ }^{30}$ Baghdad, Iraq $2013^{31}$ and the United Kingdom 2011,22 which is an unfavorable profile about cardiovascular risks ${ }^{33}$ and there was no study against it. In this study, we found that there was a statistically significant elevation in all of the serum triglycerideable 2 , serum total cholesterolable 2 and serum low density lipoproteins in comparisons to control groups. Our findings were in accordance with those of other studies that have evaluated lipid profiles in RA patients as done in Pakistan 2012, ${ }^{25}$ Tunisia $2011,{ }^{26}$ Malaysia 2012, ${ }^{28}$ South India ${ }^{29}$ and Saudi Arabia 2013. ${ }^{30}$ Our finding not matched with the study done in Turkey $1999^{34}$ and in Baghdad $2004^{35}$ that characterized by reduction of all serum total cholesterol, triglyceride and low density lipoproteins. Only three previous studies measured serum very low density lipoproteins (serum VLDL) in comparison to control. In Malaysia 2012, they determined serum VLDL, and there was a significant elevation of it, and this agreed with our findings but didn't match with a study done in Turkey $1999^{34}$ and Baghdad $2004^{35}$ characterized by a significant reduction of serum VLDL and this may be due to the sample size. In this study we correlated dyslipidemia and disease activity score and no statistically significant association was found between disease activity status (remission, low, mild, moderate and high) and presence of dyslipidemia; this was similar to a study done in Pakistan in 2012. ${ }^{25}$

\section{Conclusion}

Dyslipidemia has a higher significant prevalence among RA patients in comparison to control groups. Dyslipidemia was high among RA patients with active disease but not significant. There was a significant reduction of serum HDL compared to control, and this increases the risk of atherosclerosis. There was a significant elevation of other lipid profile in comparison to control groups with a significant relation between TG and ESR. Dyslipidemia among RA patients are common, and this increases the risk of cardiovascular disease and mortality among RA patients, more aggressive and early lipid management including greater use of statin therapy may be appropriate to reduce cardiovascular disease among RA. 
Additional prospective, long-term studies are needed to comprehensively determine the role of inflammation and the impact of biologics on lipid levels and cardiovascular outcomes in patients with RA. Cardiovascular screening should be recommended every six months to once yearly in Erbil city.

\section{Conflicts of interest}

The authors report no conflicts of interest.

\section{References}

1. Doherty $M$, Lanyon $P$, Ralston SH. Rheumatoid arthritis. Boon NA; College NR; Walker BR; Hunter JAA. Davidson's principles and practice of medicine. Churchill Livingstone; 2006. P. 1101-6.

2. Taysi S, Polat F, Gul M, Sari RA,Bakan E. lipid peroxidation, some extracellar antioxidants and antioxidant enzymes in serum of patients with rheumatoid arthritis. Rheumatol Int 2002;21: 200-4.

3. Heimick CG, Flson DT, Lawrence RC, Gabriel $S$, Hirsch R, Kwoh CK, et al. Estimate of the prevalence of arthritis and other rheumatic conditions in the US. Part I. Arthritis Rheum 2008; 58 $(1): 15-25$.

4. National Institute of Arthritis and Musculoskeletal and Skin Disease. "Handout on health: Rheumatoid Arthritis". April 2009.Retrieved 2013-03-26.

5. Tehlirian CV, Bathon JM. Rheumatoid arthritis. Klippel JH ,Stone JH,Crofford LJ,White $\mathrm{PH}$. Primer on Rheumatic diseases ,NY,USA.Springer Science+Business Media 2008; P. 114-21.

6. Symmons D, Barrett E, Bankhead C. The occurrence of rheumatoid arthritis in the United Kingdom: results from the Norfolk Arthritis Register. Br J Rheumatol 1994; 33:735-9.

7. Waldenburger JM, Firestein GS. Rheumatoid arthritis. Klippel $\mathrm{JH}$, Stone $\mathrm{JH}$, Crofford LJ, and White $\mathrm{PH}$. . Primer on the Rheumatic Disease, New York, USA: Springer Science and Business Media; 2008. P.122- 32

8. Ebringer A, Rashid T. Rheumatoid arthritis is an autoimmune disease triggered by Proteus urinary tract infection. Dev Immunol 2006; 13(1): 41-8.

9. Dieppe P. Osteoarthritis, in Primer on the Rheumatic Diseases. 2008, Springer. p. 114.

10. Jacoby R, Cosh J, Jayson M. early stages, and prognosis of rheumatoid arthritis : a clinical study with 100 patients with 11 years of follow -up. Br Med J 1973;2:96-100.

11. Ralston $\mathrm{SH}$, Doherty M. Rheumatoid arthritis. In: Colledge NR; Walker BR; Ralston 11.S.H. (editors). Davidson's principles and practice of medicine, $21^{\text {st }}$ ed. Churchill Livingstone; 2010. P. 1088-92.
12. Spellman CW. Strategies for optimizing lipid treatment outcomes. J Am Osteopath Assoc 2003; 103:S12-5.

13.Isomaki Ha, Mutru O, Koota K, Death rate and cause of death in patients with Rheumatoid Arthritis. Scand J Rheumatol 1975; 4:205-8.

14. Prior P, Symmons DPM, Scott DL, Brown R, Hawkins CF. Causes of death in rheumatoid arthritis. Br J Rheumatol 1984 23; 92-9.

15. Rossner S. Further studies on serum lipoproteins in connective tissue disease. Atherosclerosis 1978:31:93-9.

16. Leong $\mathrm{KH}$, Koh $\mathrm{ET}$, Feng $\mathrm{PH}$, Boey $\mathrm{ML}$. Lipid profiles in patients with systemic lupus erythematosus.J Rheumatol 1994;21: 1264-7.

17. Maradit-Kremers $\mathrm{H}$, Crowson CS, Nicola PJ, Ballman KV, RogerVL, Jacobsen SJ, et al. Increased unrecognized coronary heart disease and sudden deaths in rheumatoid arthritis: A population-based cohort study. Arth \& Rheum 2005; 52(2):402-411.

18. Wolfe F, Freundlich B, Straus WL. Increase in cardiovascular and cerebrovascular disease prevalence in rheumatoid arthritis. J Rheumatol 2003; 30: 36-40.

19. WHO Expert Committee. Physical status: the use and interpretation of anthropometry. WHO Tech Rep Ser 1995; 854:424-38.

20.Alamanos Y, Voulgari PV, Doros AA. Incidence and prevalence of rheumatoid arthritis based on 1987 American College of Rheumatology criteria: A systematic review. Semin Arthritis Rheum 2006; 36(3): 182-8.

21. Abdul-Qahar ZH, Al-Osami MH, Al-Asady. Prevalence of Metabolic Syndrome in Iraqi Patients with Rheumatoid Arthritis. IOSR Journal of Dental and Medical Science (IOSRJDMS). 2013;11(1):69-72.

22. Kotzin BL: The role $f B$ cells in the pathogenesis of Rheumatoid Arthritis. J Rheumatol Suppl 2005; 73:14-7.

23. Nisar A, Rasheed $U$, Aziz W,Farooqi AZ. Prevalence of Dyslipidemia in Autoimmune Rheumatic Diseases.Journal of the college of Physicians and Surgeons Pakistan 2012;22 (4):235-9.

24. Zrour SH, Neffeti FH, Sakly N , Saoussen $\mathrm{H}$,Korbaa $\mathrm{Y}$, et al. lipid profile in Tunisian patients with Rheumatoid Arthritis. 2011; 30 (10):1325-31.

25. Steiner G, Urowitz MB. Lipid profiles in patients with rheumatoid arthritis: mechanisms and the impact of treatment. Semin Arthritis Rheum 2008; 38:372-81.

26.Manjunatha Goud BK, Sarsina Devi O, Bhavana N, Devaki RN, Deepa K, Niveditha S. Nutritional Antioxidants and lipid profile in newly diagnosed Rheumatoid arthritis patients. The International Medical Journal Malasysia IMJM 2012; 11 (1):5-8. 
27. Vinapamula KS, Manohar SM, Bitla AR, Kanduri R, Bhattaram SK, Pemmaraju SR. Evaluation of dyslipidaemia in patients with rheumatoid arthritis in South Indian population.Indian Journal of Rheumatology 2013; 8 (4):155-60.

28. Bahlas S, Ahmed MM. Lipid levels and association with disease activity in RA and SLE in Saudi Arabia 2013; 11 (7)1-6.

29. Ameer KA, Alosami MH, Salih ES. Comparative study of predicting the risk of cardiovascular diseases in active RA Iraqi patients by traditional and non traditional methods. GJBB 2013; 2(4):522-6.

30. Georgiadis AN, Papavasiliou EC, Lourida ES, Alamanos Y, Kostara C, Tselepis AD, et al. Atherogenic lipid profile is a feature characteristic of patients with early rheumatoid arthritis: effect of early treatment: a prospective, controlled study. Arthritis Res Ther 2006; 8:R82.

31.Dursunoglu D, Evrengul $H$, Polat $B$, Tanriverdi $H$, Cobankara V, Kaftan A, et al. Lp(a) lipoprotein and lipids in patients with rheumatoid arthritis: serum levels and relationship to inflammation. Rheumatology international 2005; 25: 241-5.

32.Borman $P$, Seçkin ü , Yücel M. dyslipidemia in patients with RA and Osteoarthritis: Physical medicine 1999;2(3) 5-9.

33. Al-Zaidi GH, Abdulsamad T. Serum lipids in patients with active rheumatoid arthritis and its relation to drug therapy: J Fac Med Baghdad 2005; 47(1): 35-9. 